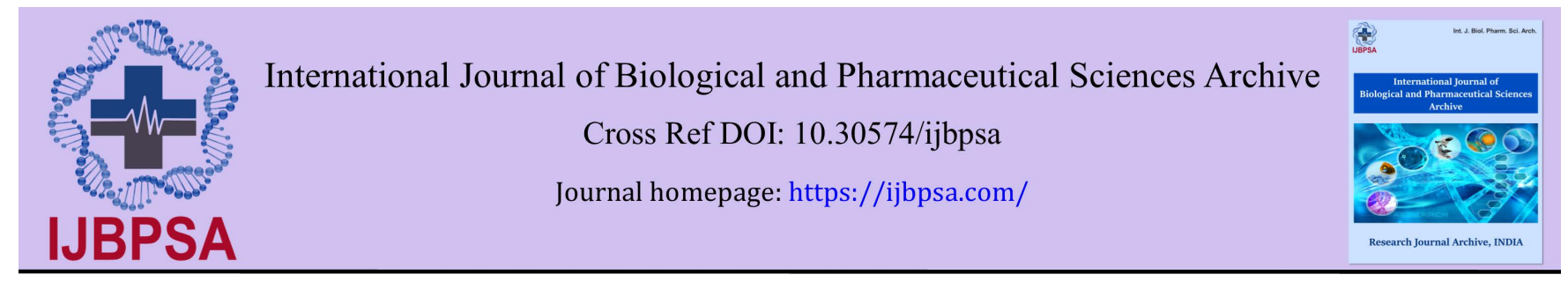

(RESEARCH ARTICLE)

\title{
Genetic diversity of Clarias anguillaris from the Bakoye River in Mali
}

\author{
Ramata Diop 1, ${ }^{*}$, Adama Konate 1, Rokiatou Fane 1, Nanourou Dembele 1, Sognan Dao 1, Drissa Konate 1, Oumar \\ Ouattara ${ }^{1}$ Youssouf Sanogo ${ }^{1}$, Fassé Samake ${ }^{2}$ and Diakaridia Traore ${ }^{1}$ \\ ${ }^{1}$ Faculty of Sciences and Techniques, University of Sciences, Techniques and Technologies of Bamako, BP E. 3206 Bamako, \\ Mali. \\ ${ }^{2}$ Institute of Applied Sciences, University of Sciences, Techniques and Technologies of Bamako, BP E. 3206 Bamako, Mali.
}

International Journal of Biological and Pharmaceutical Sciences Archive, 2021, 01(02), 145-152

Publication history: Received on 14 April 2021; revised on 18 May 2021; accepted on 21 May 2021

Article DOI: https://doi.org/10.30574/ijbpsa.2021.1.2.0039

\begin{abstract}
Clarias anguillaris is a wild species found in River basins in Mali. It is the species most commonly used in fish farming in community stockings. However, it excites little study on the genetic diversity of this species in the natural environment in Mali. The present study focused on the genetic diversity of Clarias anguillaris from the Bakoye River, a tributary of the Senegal River in Mali. A total of (8) microsatellite markers were applied to 47 samples taken at random from the River. The markers were Cga02, Cga03, Cga06, Cga10, Cba11, Cba19, Cba20 and Cma12. The number of alleles, the number of genotype, genetic diversity, Polymorphism Information content (PIC), observed and expected heterozygosity were determined. The results showed that the number of alleles ranged from 1 to 7 , with an average of 4.25 per locus. The mean rate of observed heterozygosity was 0.34 lower than that of expected heterozygosity which was 0.48 indicating nonconformity of the Hardy-Weinberg equilibrium. The allele frequency ranged from 0.35 at the Cba19 locus to 1 at the Cba11 locus, with a mean of 0.62 . Genetic diversity ranged from 0 for Cba11 to 0.75 for Cba19. The markers Cga02, Cga03, Cga06, Cba19, Cba20 and Cma12 were polymorphic with an average peak of 0.42 . The phylogenetic tree presented two groups of genotypes showing diversity within the species. Group I comprised $60.42 \%$ of individuals and group II presented $39.58 \%$ with 3 subgroups (A, B and C). The genetic distance (0.05) indicates little differentiation between individuals.
\end{abstract}

Keywords: Clarias anguillaris; Genetic diversity; Microsatellite marker; Bakoye River; Mali

\section{Introduction}

The River basins of Mali made up of the Niger, Senegal and Volta Rivers contain two species of Clarias [1]. These are Clarias anguillaris and Clarias gariepinus. The controlled landings of catches of these species show 4,873 tonnes out of the 98,332 tonnes of fish caught in Mali in 2017 [2]. This indicates the importance of these species for fishing but also for fish farming [3]. The fisheries and aquaculture sector must therefore respond to priorities such as food security and the fight against poverty while ensuring the conservation of biodiversity [3]. This is only possible with a good knowledge of the biology and genetics of fish of economic interest including species of the genus Clarias in Mali [4].

The Clarias have been the subject of numerous studies in West Africa [5, 6]. In Mali, genetic studies focused on Clarias reared in Clarias anguillaris fish farming [7]. In view of the importance of Clarias anguillaris for village fish farming in the context of community stocking and the uncontrolled introduction of allochthonous strains by fish farmers, the present study was initiated with a view to the genetic characterization of the species for its conservation.

\footnotetext{
* Corresponding author: Ramata Diop

Faculty of Sciences and Techniques, University of Sciences, Techniques and Technologies of Bamako, BP E. 3206 Bamako, Mali.. 
The objective was to determine the genetic makeup of the populations of Clarias anguillaris from the Bakoye River, a tributary of the Senegal River in Mali with a view to better management of these genetic resources to be used in conservation programs and selection of wild strains. For this purpose, genetic markers were used for the preliminary genetic characterization of two species of catfish in Nigeria [8].

Genetic markers offer great advantages by allowing the direct assessment of genetic diversity [9]. They are powerful instruments for detecting the genetic uniqueness of individuals, populations or species [10,11]. Their use concerns the conservation, the management of natural resources in relation to the impact of domestic populations on wild populations and the impact of the introductions of exotic species or on the improvement of stocks through selection assisted by markers [12 - 17].

\section{Material and methods}

The fish were collected from the landing stages along the Bakoye River, a tributary of the Senegal River in Mali, having its source in Guinea (Figure 1). The sampling area is located in the Sudanian zone.

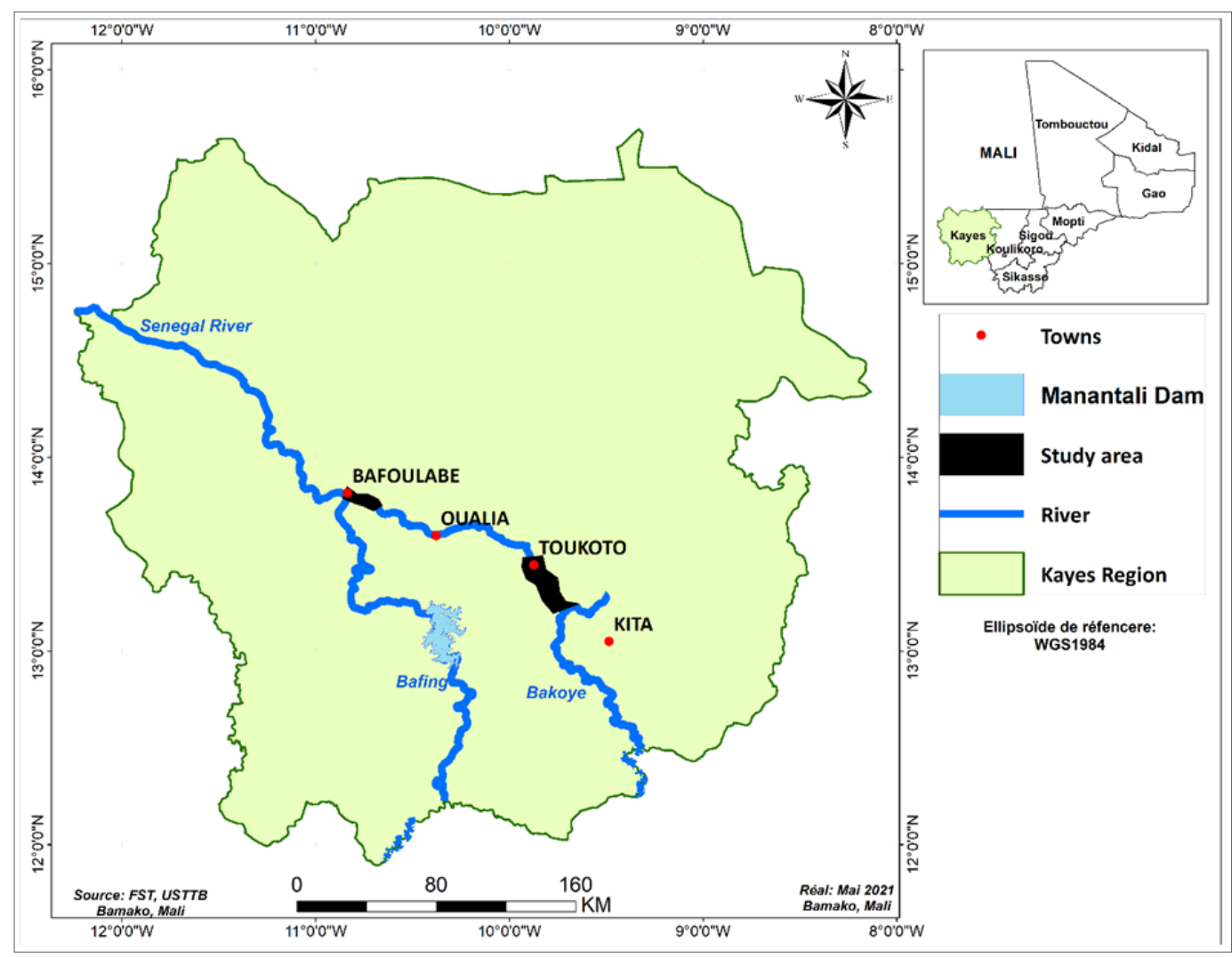

Figure 1 Localization of study area and fish Clarias anguillaris sampled in Bakoye River.

A total of 47 fish samples were collected then stored in coolers and transported to the laboratory for genetic analysis. Deoxyribonucleic acid (DNA) extraction was performed on each fish from a piece of fin collected and stored at $-20^{\circ} \mathrm{C}$. The tissues were digested in a mixture composed of $250 \mu \mathrm{l}$ of lysis solution (CTAB), $20 \mu \mathrm{l}$ of proteinase K solution and incubated at $56^{\circ} \mathrm{C}$ for two hours in a water bath. Total DNA was extracted using the Promega Purification Kit, according to the manufacturer's recommendations. The DNA samples thus extracted were stored at $4^{\circ} \mathrm{C}$.

DNA extracts were amplified using 8 pairs of microsatellite primers. A reaction mixture with a total volume of $15 \mu \mathrm{l}$ was prepared from the ingredients of the promega kit. The mixture consisted of $4.2 \mu \mathrm{l}$ of water, $7.5 \mu \mathrm{l}$ of master green, $0.6 \mu \mathrm{l}$ of the round trip primers and 1.5 or $2 \mu \mathrm{l}$ of the DNA. The reaction mixture was then distributed among the Polymerase Chain Reaction (PCR) micro tubes, then homogenized using the vortex. The micro tubes were then introduced into the Thermocycler (Alpha unit TM Block Assembly for PTC DNA Engine TM Systems) for amplification by adopting the following program shown in Table 1. 
Table 1 Amplification program

\begin{tabular}{|l|l|l|}
\hline \multicolumn{1}{|c|}{ Steps } & Temperature $\left.{ }^{\circ} \mathrm{C}\right]$ & Time \\
\hline Initial denaturation & 94 & $5 \mathrm{~min}$ \\
\hline Denaturation & 94 & $1 \mathrm{~min}$ \\
\hline Hybridization & Based on Simple Sequence Repeats (SSRs) & $45 \mathrm{sec}$ \\
\hline Elongation & 72 & $1 \mathrm{~min}$ \\
\hline Final elongation & 72 & $10 \mathrm{~min}$ \\
\hline Conservation & 4 & $\infty$ \\
\hline
\end{tabular}

The cycle (denaturation, hybridization, and elongation) was repeated 35 times.

Table 2 The primers with their sequence and their hybridization temperature in the present study

\begin{tabular}{|c|c|c|}
\hline Primer & Sequence & Temperature $\left[{ }^{\circ} \mathrm{C}\right]$ \\
\hline \multirow[t]{2}{*}{ Cga02 } & F:TACAGCGTCGATAAGCCAGG & 57.3 \\
\hline & R:ACCTCTGAGATAAAACACAGC & \\
\hline \multirow[t]{2}{*}{ Cga03 } & F : CACTTCTTACATTTGTGCCC & 54.3 \\
\hline & R : ACCTGTATTGATTTCTTGCC & \\
\hline \multirow[t]{2}{*}{ Cga06 } & F:CAGCTCGTGTTTAATTTGGC & 58.3 \\
\hline & R:TTGTACGAGAACCGTGCCAGG & \\
\hline \multirow[t]{2}{*}{ Cga10 } & F:GCTGTAGCAAAAATGCAGATG & 57.8 \\
\hline & R:TCTCCAGAGATCTAGGCTGTC & \\
\hline \multirow[t]{2}{*}{ Cba11 } & F : CACCGCGCTCGTCATTCCATAGA & 64.0 \\
\hline & R:CTGCGCGGGTTTCAGAATGTTAGG & \\
\hline \multirow[t]{2}{*}{ Cba19 } & F : CAGGGCTAAATTACCCATAATCA & 58.0 \\
\hline & R: GGCATGTGTTATAACATGTGAGG & \\
\hline \multirow[t]{2}{*}{ Cba20 } & F : GAAACACGCCATCATGCCTAATA & 57.0 \\
\hline & R: CCAAACGGAGCGGACAGG & \\
\hline $\mathrm{Cm} 12$ & $\begin{array}{l}\text { F-5'-ATG ACC CTG TAA ATC TCC-3' } \\
\text { R-5'-CTA CAT TCT CTC CGT CTCT-3' }\end{array}$ & 53.0 \\
\hline
\end{tabular}

\subsection{Data analysis}

The size of the alleles of each microsatellite marker was determined in base pair using the E-Capt software version 15.06. The diversity of each locus was analyzed on the basis of the following five statistical parameters: number of alleles, frequency of alleles, and number of genotypes, genetic diversity and PIC (Polymorphism Information Content). The genetic distance matrix was calculated with Power Marker software version 3.25 [18]. The phylogenetic tree was constructed by the UPGMA method (Unweighted Pair Group Method with Arithmetic Mean) and edited with MEGA 7.0 software. 


\section{Results}

\subsection{Polymorphism of microsatellite loci analyzed}

The Cga microsatellite markers isolated for the characterization of Clarias gariepinus [19] and the Cba markers on Clarias battracus [20] were applied to the Clarias anguillaris of the Bakoye River (Table 2). The statistics of the parameters, as well as the number of alleles identified, the observed and expected heterozygosity and the HardyWeinberg equilibrium are presented in (Table 3).

In total, 34 alleles were identified for a set of eight (8) microsatellite markers analyzed, with an average number of 4.25. The variation in allele size was small for the Cba11 locus. Genetic diversity ranged from 0.00 for Cba11 to 0.75 for the Cba19 marker. The information content polymorphism (PIC) ranged from 0.00 to 0.67 with a mean value of 0.42 . The observed heterozygosity ranged from 0.00 to 0.95 .

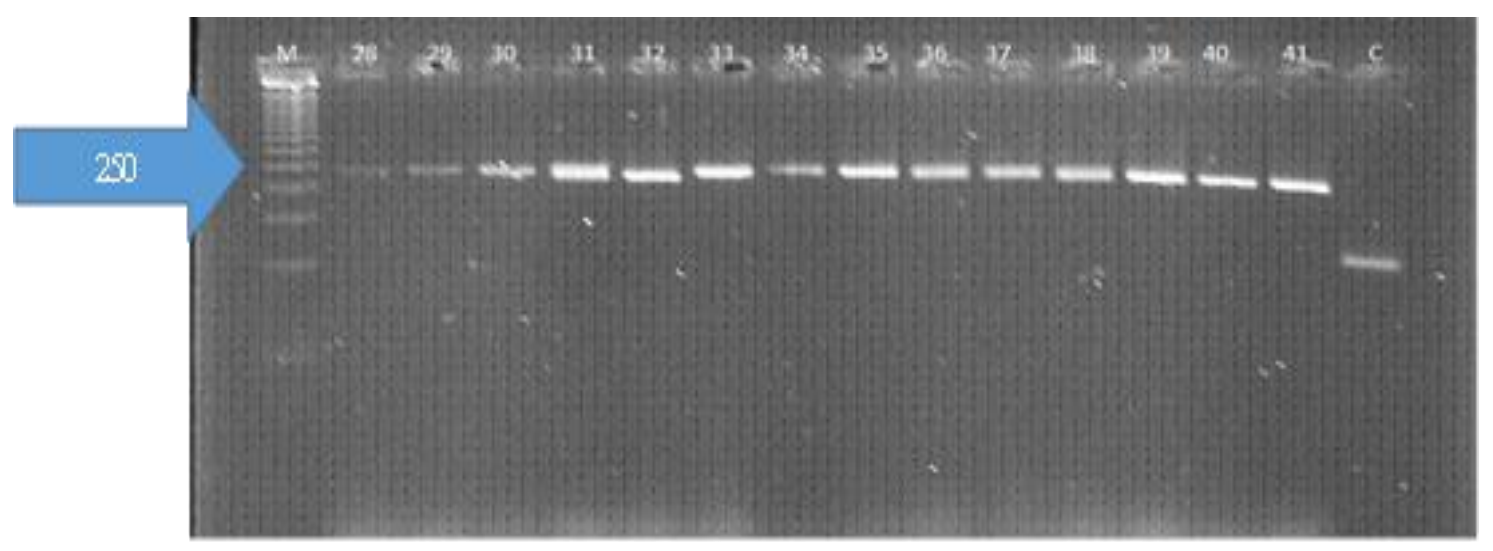

Figure 2 Migration profiles of DNA samples from Clarias anguillaris, amplified with the Cba19 marker on 3\% metaphor gel. M: Marker, 28-41: samples of Clarias anguillaris; C: negative control

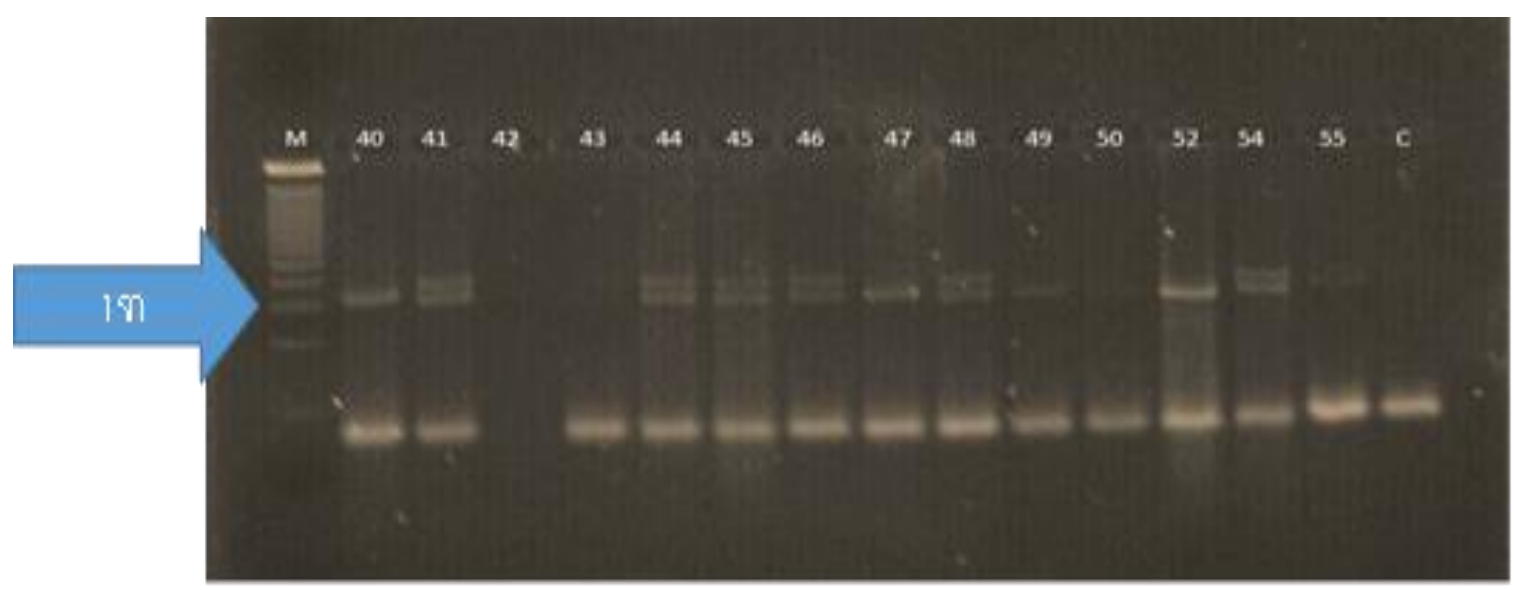

Figure 3 Migration profiles of DNA samples from Clarias anguillaris, amplified with the Cga03 marker on 3\% metaphor gel. M: Marker, 40-55: sample of Clarias anguillaris; C: negative control 
Table 3 Allele frequencies, observed and heard heterozygosity genetic diversity, PIC obtained with the two microsatellite markers Table 3: allele frequencies, heterozygous genetic diversity observed and heard, PIC obtained with the two microsatellite markers

\begin{tabular}{|l|l|l|l|l|l|l|l|l|l|l|l|}
\hline Marker & Number of allele & Allele size & Allelic frequency & Genetic diversity & PIC & I & Ho & He & uHe & F & HWE \\
\hline CGA02 & 4 & $100-110$ & 0.58 & 0.57 & 0.51 & 0.689 & 0.8 & 0.496 & 0.504 & -0.612 & $* * *$ \\
\hline CGA03 & 3 & $200-150$ & 0.58 & 0.5 & 0.4 & 0.692 & 0.95 & 0.499 & 0.512 & -0.905 & $* * *$ \\
\hline CGA06 & 7 & $200-124$ & 0.48 & 0.7 & 0.67 & 1.12 & 0.32 & 0.647 & 0.66 & 0.506 & $* *$ \\
\hline CGA10 & 6 & $142-105$ & 0.81 & 0.33 & 0.32 & 1.089 & 0.556 & 0.66 & 0.699 & 0.159 & ns \\
\hline Cm12 & 3 & $126-120$ & 0.6 & 0.51 & 0.41 & 0.659 & 0 & 0.466 & 0.471 & 1 & $* * *$ \\
\hline Cba011 & 1 & 250 & 1 & 0 & 0 & 0 & 0 & 0 & 0 & $\#$ \#/A & \\
\hline Cba20 & 3 & $120-110$ & 0.6 & 0.49 & 0.39 & 0.667 & 0.021 & 0.474 & 0.479 & 0.956 & $* * *$ \\
\hline Cba19 & 7 & $250-220$ & 0.35 & 0.75 & 0.7 & 1.12 & 0.053 & 0.636 & 0.645 & 0.917 & $* * *$ \\
\hline Moy & 4.25 & & 0.625 & 0.481 & 0.42 & 0.76 & 0.34 & 0.48475 & 0.49625 & $\#$ N/A & \\
\hline
\end{tabular}

PIC = Information polymorphismecontent; I = Shannon Information Index; Ho = Observed heterozygosity; He = Expected heterozygosity $\mathrm{uHe}=$ Impartial expected heterozygosity; F = Fixation index; HWE = Hardy Weinberg equilibrium 


\subsection{Phylogenic relationship}

Analysis of the PCR-SSR data with Darwin version 6 software according to the UPGMA method allowed the genotypes to be grouped into two groups (I, II). Group 1 consisted of $60.42 \%$ individuals and group II with $39.58 \%$ individuals. . This last group is divided into three sub-groups (A, B and C). The genetic distance was equal to 0.05 .

The distribution of individuals into two groups shows diversity within the Clarias anguillaris of the Bakoye River. Individuals who were in the same group have alleles in common. Those in the same subgroup were genetically identical.

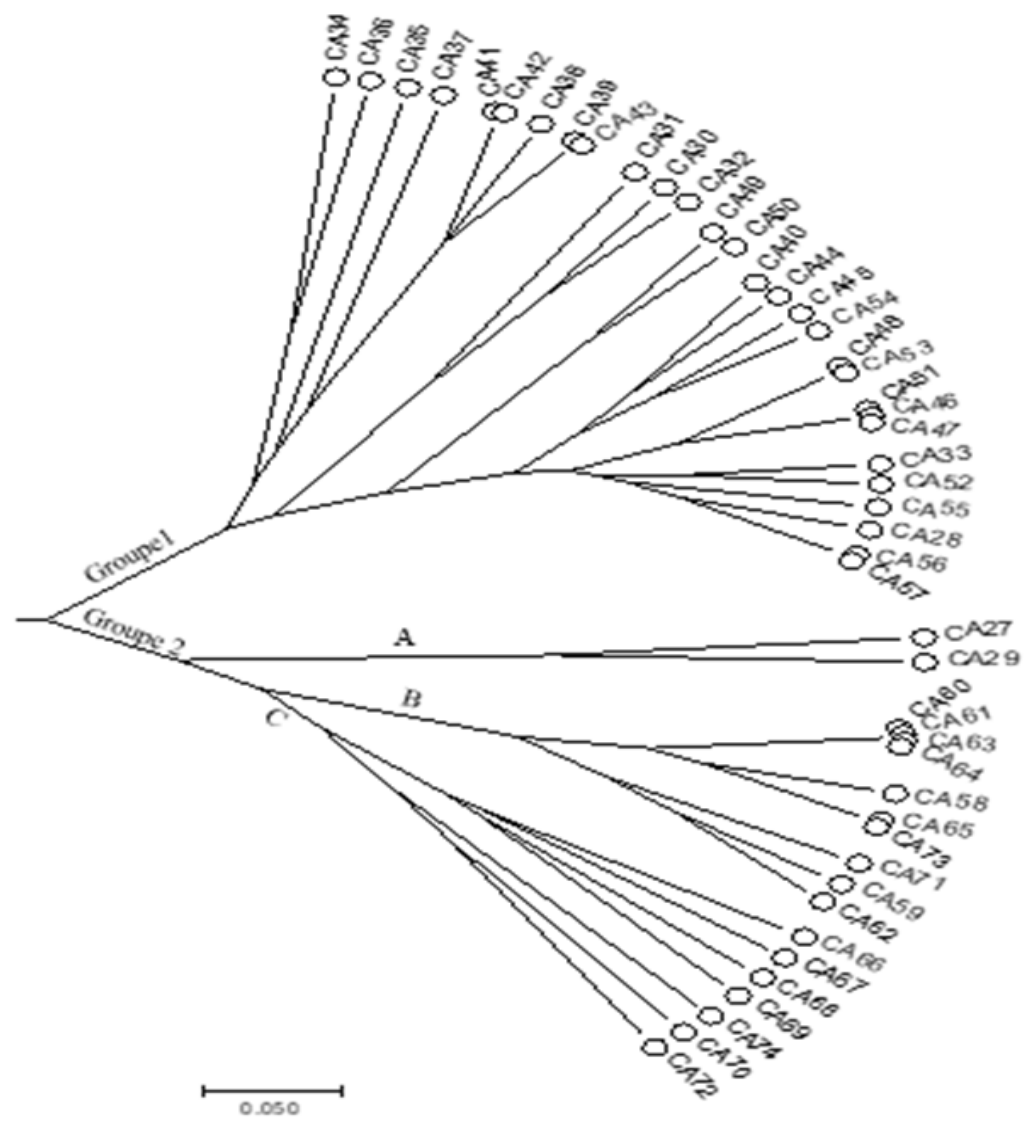

Figure 4 Phylogenic tree of Clarias anguillaris from the Bakoye River (Source: this study)

\section{Discussion}

A set of 8 microsatellite markers were used to study the genetic diversity of Clarias anguillaris from the Bakoye River, a tributary of the Senegal River in Mali. Only the Cba11 marker was monomorphic, the others being polymorphic. The information content polymorphism (PIC) ranged from 0.00 to 0.67 with a mean value of 0.42 . This means that the markers were not very polymorphic. This ICP value is less than 0.45 and 0.49 observed in Clarias gariepinus in Nigeria [21].

The variation in allele size was small for the Cba11 locus, indicating that there is no difference between individuals in the population at the locus specified by this marker. The number of alleles varies from one marker to another and for the same marker from one species to another [20]. In Clarias anguillaris, autors obtained 6 alleles with Cga02, 8 alleles with Cga03, 5 alleles with Cga06 and 9 alleles with Cga10. In the present study, with the same markers, 4, 3, 7 and 6 alleles were observed [19]. This difference could be explained by the genetic constitutions specific to the populations of Clarias anguillaris concerned.

The heterozygosity for the eight microsatellite markers ranged from 0.00 to 0.95 with a mean value of 0.34 . Some markers exhibited a deficit of heterozygosity, which means that the observed heterozygosity was less than that expected at Hardy Weinberg equilibrium. An excess of heterozygosity to certain microsatellite markers has been observed. Thus, the observed heterozygote frequency (Ho) was higher than that expected at Hardy Weinberg's equilibrium with the 
heard heterozygosity (He) between 0.00 and 0.66 . This situation can generate a flow of foreign genes in populations. But also by community stocking and the uncontrolled introduction of allochthonous strains by fish farmers.

The deviation of the Hardy-Weinberg equilibrium can occur due to the mixing of heterogeneous gene pools [22]. The reduction in the size of a population is considered to be one of the rare factors which may be responsible for a deviation from the equilibrium of Hardy Weinberg [23].

The heterozygosity value found in this study was lower than that found in individuals of Clarias anguillaris in Sangkuriang (0.43) and Paiton (0.602) in Indonesia [24]. This value is also lower in other species of the Clariidae family [8] in individuals of Clarias gariepinus (0.45) and Heterobranchus bidorsalis (0.44). On the other hand, it is higher than that observed in populations of Clarias gariepinus from Lokoja (0.12) and Asejire (0.40) in Nigeria [21]. The difference could be explained by the number of markers used and the level of diversity within the fish samples collected. . The heterozygosity value is also lower than the value observed by d'autres auteurs who obtained 0.52 with the markers (Cga01, Cga02, Cga03; Cga06 Cga09; Cga010) applied to individuals of Clarias gariepinus [25].

\section{Conclusion}

The study distinguished two genetic groups of Clarias anguillaris in the Bakoye River in Mali. The number of allele ranged from 1 to 7 with an average of 4.25 for a total of 34, with a diversity of 0.481 and an average information content polymorphism (ICP) of 0.42 . The average rate of heterozygosity is lower than the heard heterozygosity of the HardyWeinberg equilibrium.

The results obtained give indications on the genetic diversity of Clarias anguillaris in the Bakoye River in Mali. They will serve as references for genetic conservation actions in order to minimize the genetic losses of this species of fish in its natural environment.

The study should be extended to populations of Clarias anguillaris from other Rivers in Mali to establish overall genetic diversity.

\section{Compliance with ethical standards}

\section{Acknowledgments}

The authors thank the Competitive Fund for Research and Technological Innovation and the National Center for Scientific and Technological Research of Mali for funding field research, the fishing communities for their frank collaboration and the anonymous people who kindly participated reading this article.

\section{Disclosure of conflict of interest}

The authors declare that they have no conflict of interest.

\section{References}

[1] Quensière J. La pêche dans le delta central du Niger : approche pluridisciplinaire d'un système de production halieutique. Edition (Karthata). Bio-écologiste ORSTOM ; rue Lü Fayette, Paris. 1994.

[2] SIPA (Recueil des données du système d'informations sur la Pêche et l'aquaculture) (2010-2017). 2010; 1-12.

[3] FAO. La situation mondiale de l'alimentation et de l'agriculture. 2014; 1-157.

[4] Vanden BJP, Bernacsek GM. Source book for the inland fishery resources of Africa. Food and Agriculture Organization. 1990; $1: 240$.

[5] Teugels GG. A Systematic Revision of the African Species of the Genus Clarias (Pisces; Clariidae). Annales Musée Royal de l'Afrique Centrale. 1986; 247: 1-199.

[6] Paugy P, Lévéque C, Teugels GC. Poissons d'eaux douces et saumâtres de l'Afrique de l'ouest (Tome 2). 2003.

[7] Diop R, Konaté A, Traore D, Sanogo Y, Camara M. Variabilité morphométrique et génétique des espèces de Clarias utilisées en pisciculture dans la zone la zone Périurbaine de Bamako. MSAS. 2018; 1-7. 
[8] Agbebi OT, Ilaboya DE, Adebamb 00. Preliminary characterization of genetic strains in Clariidae species, Clarias gariepinus and Heterobranchus bidorsalis using microsatellite markers African Journal of Biotechnology. 2013; 12(4): 364-369.

[9] Ollivier L, Chevalet C, Foulley JL. Utilisation des marqueurs pour la caractérisation des ressources génétiques. INRA Prod. Anim. 2000; 247-252.

[10] Park LK, Moran P. Developments in molecular techniques in fisheries. Reviews in Fish. Biology and Fisheries. 1994; 4: 272-299.

[11] Askari G, Shabani A, Miandare, HK. Application of molecular markers in fisheries and aquaculture. Scientific Journal of Animal Science. 2013; 2(4): 82-88.

[12] Ferguson A, Taggart JB, Prodohl PA, Mcmeel O, Thompson C, Stone C, Mcginnity P, Hynes RA. The application of molecular markers to the study and conservation of fish populations, with special reference to Salmo. Journal of Fish Biology. 1995; 47: 103-126.

[13] Rognon X, Andriamanga M, Mcandrew B. Allozyme variation in natural and cultured populations in two tilapia species: Oreochromis niloticus and Tilapia zillii. Heredity. 1996; 76: 640-650.

[14] Verrier E. Rognon, X. Utilisation des marqueurs pour la gestion de la variabilité génétique des populations. INRAE Productions Animales. 13, HS. déc. 2000; 253-257.

[15] Liu ZJ, Cordes FJ. DNA marker technology and their applications in aquaculture genetics. Aquaculture. 2004; 238 : 1-37.

[16] Romana-Eguia MRR, Ikeda M, Basiao ZU, Taniguchi N. Genetic diversity in farmed Asian Nile and Red hybrid tilapia stocks evaluated from microsatellite and mitochondrial DNA analysis. Aquaculture. 2004; 236(1-4): 131150.

[17] Lazard J. Les paradoxes et les questionnements soulevés par l'exploitation de la biodiversité (autochtone et introduite) en aquaculture. Potentiels de la science pour l'avenir de l'agriculture, de l'alimentation et de l'environnement. 2013; 1-13.

[18] Nei M, Takezaki N .Genetic Distances and Reconstruction of Phylogenetic Trees from Microsatellite DNA. Genetics. 1996; 144(1): 389-99.

[19] Galbusera P, Volckerts FA Hellemans. Isolation and characterization of microsallite makers in the African catfish Clarias gariepinus (Burchelle 1822). 1996; 703-705.

[20] Yue GH, Kovacs B, Orban L. Microsatellites from Clarias Batrachus and their polymorphism in seven additional catfish species. Molecular Ecology Notes. 2003; 465-468.

[21] Awodiran MO, Adeniran FO, Akinwale RO, Akinwande AA. Microsatellite variability of two populations of Clarias gariepinus (siluriformes, Clariidae) in Nigeria. Vestnik Zoologii. 2019; 53(3): 195-208.

[22] Ferguson A, Taggart JB, Prodohl PA, Mcmeel O, Thompson C, Stone C, Mcginnity P, Galbusera P, Volckaert FA, Hellemans B, Ollevier F. Isolation and characterization of microsatellite markers in the Africa catfish Clarias gariepinus (Burchell 1822). Molecular Ecology. 1996; 5: 703-705.

[23] Nasren, S, Islam MN, Khan MGQ, Islam MS, Alam MS. Genetic variation and differentiation in the Stinging catfish, Heteropneustes fossilis (Bloch), populations assessed by heterologous microsatellite DNA markers. Indian J. Biotechnol. 2009; 8: 85-90.

[24] Imron, Sunandar D, Tahapari E. Microsatellite genetic variation in cultured populations of African catfish (Clarias gariepinus) in indonesia indonesian aquaculture journal. 2011; 6(1).

[25] Barasa JE, Mdyogolo S, Abila R, Grobler JP, Skilton RA, Bindeman H, Ndotono NM, Chemoiwa EJ, Dangasuk OG, Kaunda-Arara B, Verheyen E. Genetic diversity and population structure of the African catfish, Clarias gariepinus (Burchell, 1822) in Kenya: implication for conservation and aquaculture. Belgian Journal of Zoology. 2017; 147(2): 105-127. 